\title{
TRANSMISSION CONTROL OF COVID-19 RADIOGRAPHERS IN RADIOLOGY INSTALLATION AT KENDAL DISTRICT HOSPITAL
}

\author{
*Lucky Restyanti Wahyu Utami', Indah Sulistyowati' \\ ${ }^{1}$ Widya Husada Semarang University \\ *lucky.restyanti@gmail.com, indahs17610@yahoo.com
}

Submitted : 12 Desember 2021 Accepted : 20 Januari 2022 Published : 27 Januari 2022

\begin{abstract}
In the midst of the ongoing COVID-19 pandemic, individuals who are most at risk of infection are those who have close contact with COVID-19 sufferers, one of which is health workers. One of the health workers who are in close contact with COVID-19 sufferers is a radiographer who is in charge of carrying out radiological supporting examinations. Health care workers who come into contact with patients can protect themselves by adhering to infection prevention and control practices, which include administrative, environmental, engineering controls, and the use of appropriate personal protective equipment. The use of appropriate personal protective equipment includes proper selection of the appropriate type of personal protective equipment, how to use it, how to remove it, how to dispose of and or wash personal protective equipment. The use of personal protective equipment is one of the efforts to prevent and control the COVID-19 infection. The objectives to be achieved in this study are to determine the control of the transmission of COVID-19 carried out by radiographers at the radiology installation of the Kendal district hospitals. The type of research used is descriptive qualitative research. The research sample used was 5 radiographers in one of the Kendal district hospitals. Collecting data uses a questionnaire and data analysis uses descriptive analysis. The results showed that respondents had controlled the transmission of COVID-19 which included procedural techniques in services in the radiology installation environment and the use of appropriate personal protective equipment.
\end{abstract}

Keywords: COVID-19 transmission control, radiographer

\section{BACKGROUND}

COVID-19 is an infectious disease caused by severe acute respiratory syndrome coronavirus 2 or SARSCoV-2, a new type of coronavirus that has never been previously identified in humans. In the heaviest cases, COVID-19 can cause pneumonia, acute respiratory syndrome, kidney failure, and death (Kementerian Kesehatan Republik Indonesia, 2021). The first case of COVID-19 was found in Wuhan, China in December 2019 (Tim Mitigasi IDI, 2021).

Special attention and efforts are needed to reduce the transmission of COVID-19 to vulnerable populations such as children, the elderly, and health service providers (Rothan, 2020).

Prevention and mitigation measures are the key to controlling the transmission of COVID-19 in health services (Direktorat Jenderal Pencegahan dan Pengendalian Penyakit, 2020). Optimal efforts that can be made by health workers in an effort to reduce transmission and break the spread of COVID-19 can be carried out with strategic and tactical steps (Ikatan Dokter Indonesia, 2020).

Control of the transmission of COVID-19 in health care facilities requires comprehensive control activities from all sides, including technical control, administrative control, and the use of personal protective equipment or personal protective equipment (Perhimpunan Spesialis Kedokteran Okupasi Indonesia, 2020).

Individuals most at risk of infection are those who have close contact with COVID-19 sufferers, one of which is health workers (Kementerian Kesehatan Republik Indonesia, 2020). Health workers who are at the forefront of treating COVID-19 sufferers have a greater risk of being infected (Perhimpunan Spesialis Kedokteran Okupasi Indonesia, 2020). One of the health workers who have close contact with COVID-19 sufferers is a radiographer who is in charge of carrying out radiological supporting examinations (Yuliana, 2020).

Health care workers who come into contact with patients can protect themselves by adhering to infection prevention and control practices, which include administrative, environmental, engineering controls, and the use of appropriate personal protective equipment. The use of appropriate personal protective equipment includes 
proper selection of the appropriate type of personal protective equipment, how to use it, how to remove it, how to dispose of and or wash personal protective equipment. The use of personal protective equipment is one of the efforts to prevent and control COVID-19 infection (Kementerian Kesehatan Republik Indonesia, 2020).

Based on the results of research conducted by Prahardi (2021), most of the radiographers in Banyumas did not play a role in controlling the spread of COVID-19. According to Hendrastutik research (2020) shows that there is a low level of alertness to the transmission of COVID-19 in health workers at the Sebelas Maret University Hospital. Meanwhile, Elfi research results (2020) show that most of the COVID-19 volunteers do not comply in carrying out efforts to control the transmission of COVID-19.

Based on the background above, the author is interested in studying further in research entitled "Transmission Control of COVID-19 Radiographers in Radiology Installation at Kendal District Hospital".

The purpose of this study is to find out how to control the transmission of COVID-19 carried out by radiographers at the radiology installation of the Kendal district hospital.

\section{METHODS}

The type of research used is descriptive qualitative research to describe the original situation in the field systematically and accurately.

The population in this study re radiographers in one of the radiology installations at the Kendal district hospital. The sample used in this study amounted to 5 radiographers.

The variable used is controlling the transmission of COVID-19 carried out by the radiographer.

\section{RESULTS AND DISCUSSION}

From the research that has been done, the following results were obtained:

Table 1 Frequency Distribution of Respondents Age Description

\begin{tabular}{ccc}
\hline Age & Frequency & Percentage $(\%)$ \\
\hline$>20$ & 4 & 80 \\
$>30$ & 1 & 20 \\
Amount & 5 & 100
\end{tabular}

Based on table 1, it can be seen that most of the respondents are 20 years old, as many as 4 radiographers (80\%).

Table 2 Frequency Distribution of Respondents Gender Description

\begin{tabular}{ccc}
\hline Gender & Frequency & Percentage $(\%)$ \\
\hline Male & 3 & Male \\
Female & 2 & Female \\
Amount & 5 & Amount
\end{tabular}

Based on table 2, it can be seen that most of the respondents are male, as many as 3 radiographers $(60 \%)$.

Table 3 Frequency Distribution of Respondents Long Working Experience Description

\begin{tabular}{ccc}
\hline $\begin{array}{c}\text { Long Work } \\
\text { Experience }\end{array}$ & Frequency & Percentage $(\%)$ \\
\hline$<5$ years & 2 & 40 \\
$>5$ years & 3 & 60 \\
Amount & 5 & 100 \\
\hline
\end{tabular}

Based on table 3 , it can be seen that some respondents have more than 5 years of work experience, as many as 3 radiographers $(60 \%)$.

To find out the control of COVID-19 transmission carried out by radiographers at the radiology installation of the Kendal district hospital, a questionnaire in the form of 7 questions was used by marking the choice of each question given according to what the respondent did while on duty. Based on the results of the questionnaire given to the research respondents, it was found that:

1. All radiographers are aware of the regulations regarding the use of personal protective equipment in hospitals during the COVID-19 pandemic. 
2. Most of the radiographers stated that there is a difference in the use of personal protective equipment used in treating COVID-19 patients and non-COVID-19 patients with a percentage of $80 \%$.

3. Hospitals encourage the use of personal protective equipment for radiology officers (radiographers) when handling COVID-19 patients by providing counseling with a percentage of $100 \%$.

4. Hospitals giving awards to radiographers who use personal protective equipment according to the provisions with a percentage of $20 \%$.

5. COVID-19 control techniques applied in radiology installations include making clear special markers regarding where to stand at the counter, queue, or sitting distance in the radiology waiting room, making barriers at the radiology registration counter, and regulating air circulation in the officer's room, the waiting room or visitor's room is changed so that pathogenic germs in the air do not contaminate the room.

6. How to use good and correct personal protective equipment to be used when on duty dealing with COVID-19 patients as a radiographer, namely using special work clothes and shoes, washing hands with water and soap, using head coverings, using masks according to activities, using layered gloves. the inside, wearing protective eyewear, using an isolation gown, using the outer gloves, and using personal protective equipment.

7. How to remove personal protective equipment properly and correctly after being used to handle COVID-19 patients as a radiographer, namely replacing the outer layer of gloves with new gloves and then using a hand sanitizer, removing the isolation gown and outer layer of glo,ves and then using a hand sanitizer, remove the protective glasses and then use hand sanitizer, remove the mask and then use hand sanitizer, remove the headgear and then use hand sanitizer, remove the inner layer of gloves then use hand sanitizer and the removal of personal protective equipment is complete.

From the results of the descriptive analysis, it was found that the control of COVID-19 transmission carried out by the respondents was under the recommendations set by the Ministry of Health of the Republic of Indonesia (2020) and the Indonesian Association of Occupational Medicine Specialists (2020). Efforts to control the transmission of COVID-19 that have been implemented include procedural techniques in services provided in the radiology installation environment and the use of appropriate personal protective equipment by radiographers.

\section{CONCLUSION AND SUGGESTIONS}

Control of the transmission of COVID-19 carried out by radiographers at the radiology installation of the Kendal district hospital, including understanding the regulations for the use of personal protective equipment, using special personal protective equipment based on indications, the hospital providing counseling, and giving awards to radiographers who use personal protective equipment according to the provisions. How to use and remove personal protective equipment properly and correctly when handling COVID-19 patients. The hospital also applies special markers related to standing, queuing, sitting distance at the radiology counter and waiting room as well as regulating air circulation in the room.

\section{REFERENCE}

Direktorat Jenderal Pencegahan Dan Pengendalian Penyakit. 2020. Pedoman Pencegahan Pengendalian Coronavirus Disease (COVID-19) Revisi Ke 4.

Elfi QR, Moh A. 2020. Upaya Pencegahan Dengan Kepatuhan Dalam Pencegahan Penularan COVID-19 Pada Relawan COVID. Journal Of Public Health Research And Community Health Development.

Hendrastutik A, Nurhasan AP, Risalina M, Coana SG, Meirina MW. 2020. Pencegahan Penularan COVID-19 Pada Tenaga Kesehatan Di Rumah Sakit Universitas Sebelas Maret. Logista Jurnal IImiah Pengabdian Kepada Masyarakat.

Ikatan Dokter Indonesia. 2020. Petunjuk Pencegahan Penularan COVID-19 Untuk Petugas Kesehatan Edisi 1.

Kementerian Kesehatan Republik Indonesia. 2020. Petunjuk Teknis Alat Pelindung Diri (APD) Dalam Menghadapi Wabah COVID-19.

Kementerian Kesehatan Republik Indonesia. 2021. Keputusan Direktur Jenderal Pencegahan Dan Pengendalian Penyakit.

Perhimpunan Spesialis Kedokteran Okupasi Indonesia. 2020. Panduan Perlindungan Bagi Pekerja Di Fasilitas Pelayanan Kesehatan Dalam Masa Pandemi COVID-19. 
Prahardi R, Syaifudin RH. 2021. Peran Radiografer Dalam Penanggulangan Penyebaran COVID-19. Jurnal Radiografer Indonesia.

Rothan HA, Byrareddy SN. 2020. The Epidemiology And Pathogenesis Of Coronavirus Disease (COVID-19) Outbreak. Journal of Autoimmunity.

Tim Mitigasi IDI. 2021. Pengendalian Teknik Dan Administrasi Untuk Mengurangi Risiko Penyebaran COVID-19.

Yuliana. 2020. Corona Virus Diseases (COVID-19); Sebuah Tinjauan Literatur. Wellness And Healthy Magazine. Volume 2. Nomor 1. 